\title{
Enhancing the Mesosystem for Adolescent Growth: Home-Based Parent Involvement and Guided Inquiry Activities for Parents and Children
}

\author{
Peter Rillero, Ph.D. \\ Associate Professor, Mary Lou Fulton Teachers College, Arizona State University
}

Received: March 5, 2015 Accepted: August 26, 2015 Published: February 1, 2016

doi:10.5296/jse.v6i1.8642 URL: http://dx.doi.org/10.5296/jse.v6i1.8642

\begin{abstract}
Parent involvement in education is almost universally recognized as a positive influence on children, their academic performance, and attitudes toward school. While studies generally support these ideas, research on parental involvement is challenged by problems including a lack of agreement about what are the key aspects of parental involvement and limited research employing a theoretical model. Focusing on parental involvement as adults helping their children at home, this study had 101 sixth-grade students complete at-home guided-inquiry science activities with their parents. Levels of participation varied but were best when the activities aligned with the school curriculum and materials were readily available. Parents and students generally had positive attitudes toward the program, with parents more positive than students and female students slightly more positive than male students. Interview and survey results suggest most parents felt they helped their child learn science. Shortages of parent time and student procrastination were problems that were identified. Many parents reported learning more about their children. The majority of students indicated they would rather work on this type of homework with a parent than work alone.
\end{abstract}

Keywords: education, science education, parent involvement, science activities, homework, mesosystem, adolescent

JEL Classification: 120, 129 


\section{Introduction}

The middle school years are important for developing attitudes about learning, school, and careers. Success in coping with transitions of schools and adolescent life influences student attitudes and academic progress (Reynolds, 1991; Veronneau, 2010). During the middle years, students form attitudes that influence their science course selection in high school and college (Farenga \& Joyce, 1998, 1999; Gennaro, Hereid, \& Ostlund, 1986; Misiti, Shrigley, \& Hanson, 1991; Simpkins, Davis-Kean, \& Eccles, 2006). "For many students, it is during these years that a desire to learn and understand the scientific world is lost" (Meichtry, 1992, p. 441).

Paradoxically, during the difficult years of adolescence many parents begin to lose touch with their children and their children's school (Carnegie Council on Adolescent Development, 1989; Epstein \& Conners, 1992; Veronneau, 2010). The transition from elementary to middle school makes being an involved parent more difficult (Berla, 1991). Instead of one main teacher in an elementary school grade, there are four to six teachers in a middle school grade, which makes it more difficult for parents to establish or maintain contact. Methods of increasing and sustaining parent involvement need to be explored (Arnold \& Birne, 1995; Caplan, Choy, \& Whitmore, 1992; Eccles \& Harold, 1993; Wimberly \& Noeth, 2004). This article describes a study of outcomes resulting from parent involvement in science activities sent home by sixth grade teachers.

\section{Literature Review}

\section{Perspectives on the Importance of Parental Involvement in Science}

There are many positive outcomes posited by educators about benefits of involving parents in education (David, 1993; Dodd \& Konzal, 2000a, 2000b; Downey, 2002; Hashmi \& Akhter, 2013; Kohl, Lengua, \& McMahon, 2000; Nye, Turner, \& Swartz, 2006; Sheldon \& Epstein, 2005; Ritblatt, Beatty, Cronan, \& Ochoa 2002; Zellman \& Waterman, 1998). Many of these proponents echo the British Government's rational for increasing parental involvement, "Parents are a child's first and enduring teachers" (Department for Education and Employment, 1998, p. 3). US Federal regulations, including the No Child Left Behind Act of 2001 and Title 1 money recipients, mandate efforts by schools to increase parental involvement (US Department of Education, 2004).

The importance of parent involvement in science education has been advocated for the last twenty years. Beyond direct observation and interaction, children's understanding of the natural and technological world is shaped by the adults in their lives (Ash, 2003; Callanan \& Jipson, 2001; Callanan \& Oakes, 1992; Crowley \& Galco, 2001; Siegel, Estrly, Callanan, Wright, \& Navarro, 2007; Verma, 1994). Children's questions persist after the school day ends; when parents assist in exploring these questions, children see that science is important (Bobbitt \& Paolucci, 1975). Parents are thought to be great role models for doing science and can "demystify the subject and identify the everydayness of science processes" (Williams-Norton, Residorf, \& Specs, 1990, p. 13). In the process of involving parents, parents may learn more about science and science instruction. 
Parents and Children Learning Science Together at Home

Many research studies show positive correlations of student science achievement with positive parent attitudes towards school, parents' educational level, and diverse measures of parent involvement (Fleer \& Rillero, 1999; George and Kaplan, 1998; Osborne \& Collins, 2000). But studies that explore interactions between parents and students doing at-home science are few. The upcoming section presents research that studied increasing parental involvement through at-home science activities.

Graika (1981) held Saturday courses for parents to learn about doing science activities with their children. Parent homework assignments required them to work on activities at home with their children. Graika observed that parents' needs resembled the needs of pre-service and post-service elementary teachers. From evaluation forms completed by parents, Graika concluded the course was a success. "Many parents reported their children's avid interest in the ideas they brought home each week. Moreover, the parents expressed appreciation for the chance to learn about science and to transmit their joy in learning to their children. The one regret mentioned was that children could not enrol in the parents' class, too" (Graika, 1981, p. $15)$.

Gennaro and Lawrenz (1992) investigated the effectiveness of take-home science kits at the elementary level. Students in first to fourth grades in a science magnet school were given the option of bringing science kits home to work on with a parent. The kits contained the materials and instructions for science activities. Six kits were available to first and third graders in the first year. Four kits were available to second and fourth graders in the second year. The participation rate was $87 \%$ of the students, with $75 \%$ bringing home five or more kits in the first year. In the second year the participation rate was $75 \%$ with $45 \%$ bringing home three or more kits. From examining activity booklets, Gennaro and Lawrenz determined "that most of the children completed most of the activities in the kits they took home" (1992, p. 989).

Both parents and students expressed positive attitudes towards the program. Girls had more positive attitudes than boys, and the authors suggest this may be a way to keep girls in the science pipeline. Parents in the treatment group changed more in their attitudes about the importance of developing their children's science interests than did the control group. There were no consistent changes in science attitude for parents or students. There were no differences between students in the treatment and control groups on a curiosity scale.

Siegel, Estrly, Callanan, Wright, and Navarro (2007) observed Mexican-American families doing science activities together. They observed that most parents used a style of communication they classified as directive. They did not find any difference in communication style based upon educational level of the parents.

Hooker (2014) explored increasing parent involvement for fourth-grade students through the use of videos to help with science homework. She observed that there was an overall positive influence of the videos on measures of parental involvement and student science achievement. 
Problems in Parental Involvement Research

After examining studies from a variety of content areas, Epstein concluded "research is needed on school and family connections in early and late adolescence in order to understand better how to help more students succeed and to prevent or reduce serious problems that may interfere with student success in school" (Epstein, 1992, p. 1141). "An added challenge is to continue to conduct research that helps improve educational policies and school practices of partnership" (Epstein \& Sanders 2000, p. 290).

There are three concerns when looking at parental involvement research. The first is the conflicting views of what parent involvement is and what components are most important (Desforges \& Abouchaar, 2003). "Parents helping in the schools" is a common measure but it might not be the most important, and it is not possible for many parents to do this on a regular basis. This study avoids this problem by considering parental involvement as parents helping with homework, where the term parent is used broadly to refer to any adult in a household. The second problem with parent involvement research is that there are relatively few intervention types of studies that have been done in science education. Indeed most of the claims that parent involvement is effective are from correlation studies (Downey, 2002). Thirdly, the studies that were done were mostly atheoretical making it difficult to develop a coordinated body of research.

\section{Conceptual Framework}

Many studies of child development consider one aspect of a child or a child's life. There are, however, many factors affecting child development, such as biology, psychology, economy, culture, or social influences, which do not occur in isolation. A greater understanding may result from taking a more ecological view that "involves the scientific study of the progressive, mutual accommodation between an active growing human being and the changing properties of the immediate settings in which the developing person lives" (Bronfenbrenner, 1979, p. 21). Bronfenbrenner's Ecological Systems Theory (1979, 1986) describes the different ecologies that pertain to individual development. These ecologies are nested within each other like Russian matryoshka dolls as shown in figure 1. 


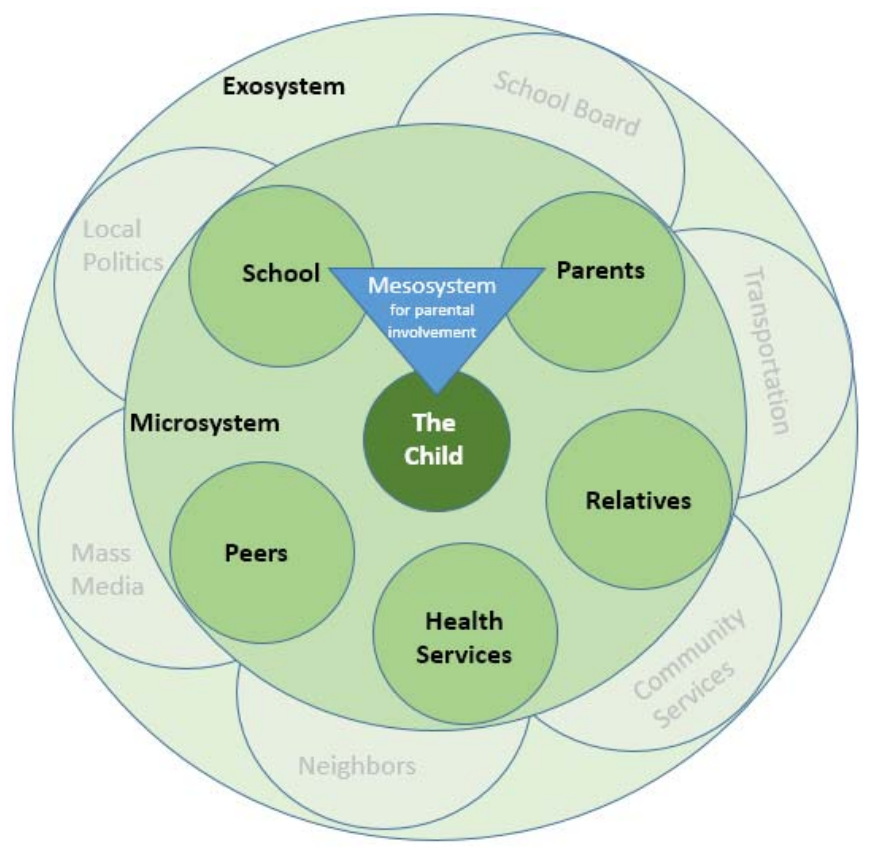

Figure 1. Important elements of Bronfenbrenner's Ecological Systems Theory for Parental Involvement

The child and his/her attributes are at the center of the ecosystem. The microsystem contains the direct relationships and interactions children have in their immediate environment, such as parents and schools. The mesosystem is a critical element as it is comprises interactions between microsystems. For studies of parental involvement in education, the most pertinent microsystem interactions are between the parents and the school. The exosystem includes the microsystems and mesosystems as well as other factors that might indirectly affect children, such as electronic media and community services. The macrosystem includes all of the aforementioned systems and it includes cultural values and customs.

Using Ecological Systems Theory for studying parent involvement in education can help researchers realize the importance of focusing on actual life settings and on the mesosystem (see Figure 1). Parent involvement is most important when it comes to interactions between parent and child about school, rather than interactions between parents and adults at school (McNeal, 2014). Indeed parent involvement efforts are not just something a school does to a parent, or a school and parent do to a child, but parental involvement needs to be conceptualized as the interplay between parent-school-and-child. The school-parent-child mesosystem deserves special scrutiny because it is linked to a child's success (Veronneau, 2010). This can be a challenge, as parents have little or no influence on what happens in classroom instruction and schools cannot mandate parental involvement. Further complicating this mesosystem, teachers and parents might have different understandings about the ability of a child and about their goals for growth and development of the child (Katz, 1984). 
While the interaction between parent and school is important, ultimately parents can be partners in the "Zone of Proximal Development" (ZPD) described as "the distance between the actual developmental level [of the child] as determined by independent problem solving and the potential development as determined through problem solving under adult guidance or in collaboration with more capable peers" (Vygotsky, 1979, p. 86). The ZPD is created by both the child's level of development and the context and goals of the interaction (Wertsch, 1985). "Children do not 'possess' zones, varying in dimension, but rather a zone may be created in the course of their collaboration with a more competent partner" (Tudge, 1991, p. 1). "The zone of proximal development defines those functions that have not yet matured but are in the process of maturation, functions that will mature tomorrow but are currently in an embryonic state" (Vygotsky, 1979, p. 86). The goal of increasing parental involvement should be to help the parent and teacher, although separated specially and temporally, work in the same ZPD with the child. "What a child can do with assistance today she will be able to do by herself tomorrow" (Vygotsky, 1979, p. 87).

\section{Methods}

\section{The Intervention and Participants}

This study explored the building of a better mesosystem between home and school microsystems by making a firm request for students and parents to conduct guided inquiry activities at home. Schools often have severe budgetary concerns, so while providing science materials to parents would make it easier for families, it is an expense many schools would rather avoid. So in this program, no science materials were sent home to the parents. Activity sheet - describing activities that use commonly available materials - were the only items provided

The study was done with six grade students at a suburban Midwestern US school that the principal characterized as having families from a moderate to low socioeconomic level. Students were required to bring home the parental involvement activity sheets. If parents couldn't do them the parents signed the activity sheet and explained why they could not complete the activity. When this was returned to the school, the child was given an alternative traditional assignment. The completed activity sheets were graded as homework. The implementation came as close to requiring parental work as the researcher and teachers felt comfortable. It was much more of a mandate than "do this if you want" or "do this for extra credit". These were required homework activities.

Ten activities were assigned, one per week of school. Because of a one-week long vacation, a camping trip, and sex education instruction requiring the dividing of classes, the program lasted 13 weeks. There were two teachers, 101 students, and their parents involved in the program.

The first eight activity sheets were based upon topics that were being studied in class. In this way the activity sheets served to connect the home and school environments by helping parents know what was being studied in school. The final two activities focused on open-ended inquiry and thus did not align to the particular science content being covered in 
class. From manipulating materials to writing answers, parents had active roles in the activities. The goal was to have parent and child doing science together.

\section{Data Sources}

To understand how participants viewed the activities and the program, data were obtained from students and parents. The completion level for each activity for each teacher was recorded, as were reasons for non-completions.

Surveys of parents and students were developed with parallel items so parent and child perspectives could be compared. Seven parents and six students were purposefully selected for semi-structured interviews with open-ended questions. The selection recruited high-, medium-, and low-level participants, who were classified based upon the number of activities completed. These parent and student interviews were conducted and analyzed to reveal personal perspectives and experiences of participants, as recommended by Patton (1990). The researcher followed a protocol with listed questions to ask. Notes were taken during the interview, and with parental permission, the interviews were also audiotape recorded.

\section{Results}

\section{Completion Levels}

Figure 2 presents the percentage of families that completed the parental-involvement at-home science inquiry activities and how that varied over time. During the program, $57.1 \%$ of the assigned activities were completed by the students in Teacher 2's class compared to a $78.6 \%$ completion rate for students in Teacher 1's class. There was a significant difference $(t=3.73$, $p<.001$ ) between the students' level of activity completion for the two teachers. The teachers proposed the following differences in their behaviour as possible reasons for the completion level differences: (a) Teacher One used a percentage grading system and Teacher Two used a check plus, check, and check minus grading system, and (b) Teacher One discussed the activities when they were returned to class but Teacher Two did not.

Despite the differing levels, the patterns of the variation of completion rates between the activities are similar for the two teachers (see Figure 2). The estimated completion rate of a normal homework assignment was between 70 to $75 \%$ for the two teachers. The levels of completion started higher than this for both teachers and ended lower. Activity four, five, nine, and ten had the lowest levels of completion.

When parents did not do an activity with their child they were asked to sign the activity sheet and provide a reason. These reasons are categorized in Table 1 for activity four. Time, materials, and sickness were recurring themes. 


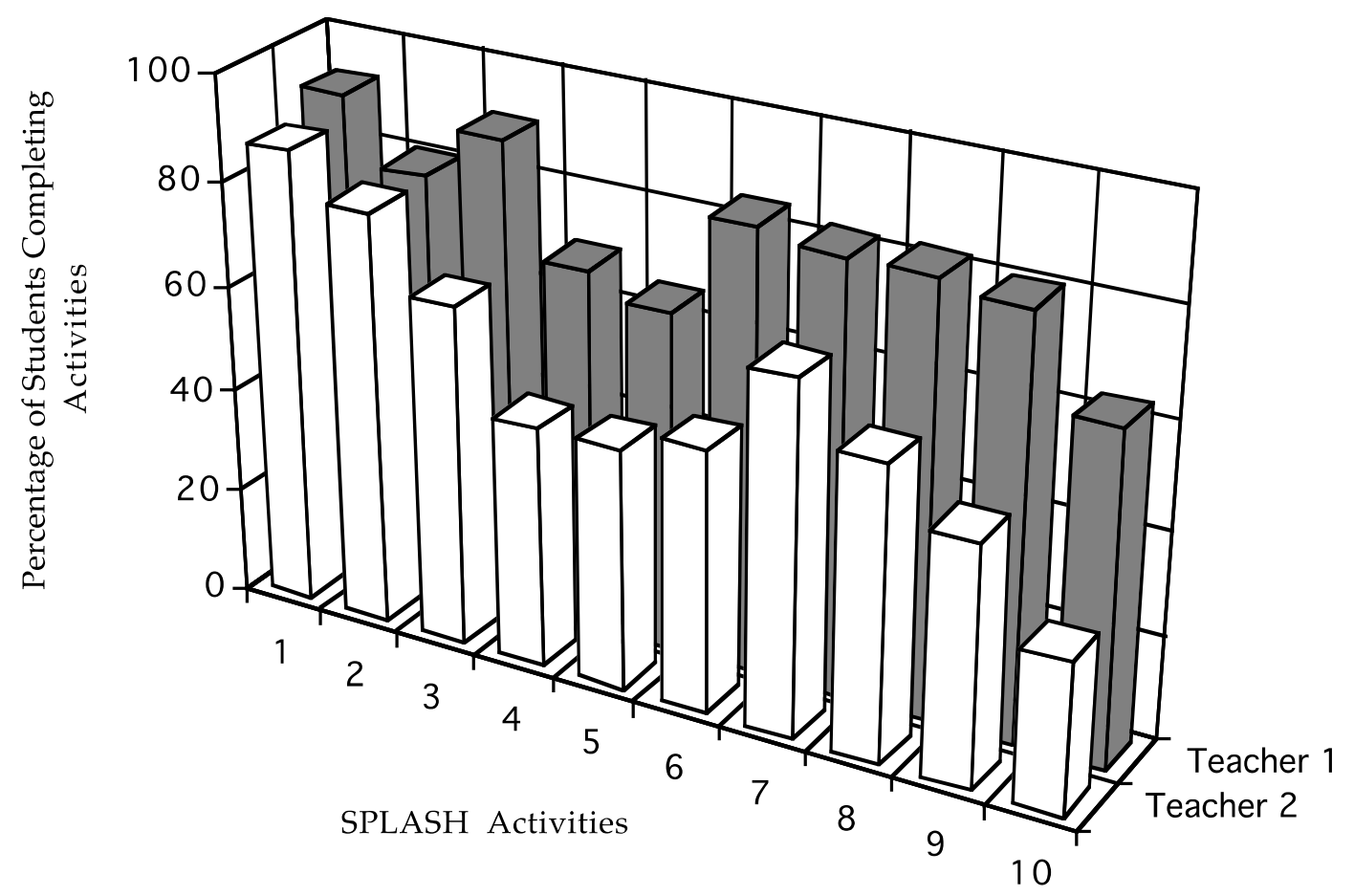

Figure 2. Activity Completion Percentages for Each Week by Teacher

Table 1. Adult Reasons for Not Doing Activity 4: Settle Down!

\section{$\underline{\text { Time Problems }}$}

"Was unable to do this activity with Emily as her Material Problems

father \& I had an appointment."

"Don't have these materials."

"We did not have time to do this activity and Mark will turn it in on Wednesday."

"We did not do this because we lacked the materials."

"We can't find the activity sheet, I'm sorry to say. Please excuse Christie for the next 2 months from her activities. I am currently working on my thesis and am

\section{$\underline{\text { Sickness Problems }}$}

"I am sorry that we cannot do at West Middle School (name changed) from 8 to 3, this activity. With Anna being then I go to work until 8:00. By the time I come home sick we did not have time to there isn't time to do the exercise. Thanks." prepare."

"Didn’t have time."

"Didn't realize this one took extra-time." 
Who Were the Parents Involved?

The majority of adults helping with each activity were the mothers of the children. After mothers, fathers were the next most likely adults to help. The parent questionnaire contained instructions stating the parent doing the most activities should complete it. Of the respondents, $81.1 \%$ of the forms were completed by mothers and $17.8 \%$ by fathers. Activity four contained a short questionnaire that was completed by the adult helping with the activity $(n=58)$. Thirty mothers $(51.7 \%)$, twenty-six fathers $(44.8 \%)$, one uncle $(1.7 \%)$, and one brother $(1.7 \%)$ worked on the activities with students.

\section{Survey of Parent Views}

How did participants feel about the program? A five-point, Likert-item questionnaire administered to parents ( $84 \%$ were returned) indicated positive attitudes towards the program and activities. A factor analysis of this section of the parent instrument revealed two factors. The factor labels with Cronbach's alpha reliability, means, and standard deviations are: Parent Views of Benefits $(\mathrm{r}=.92$, mean $=3.56, \mathrm{SD}=0.83)$ and Parent Views of Problems $(\mathrm{r}=.82$, mean $=2.24, \mathrm{SD}=0.68)$. Parents tended to agree with the items describing potential benefits of the program, and parents tended to disagree with items describing potential problems with the program.

The mean score on Parent Benefits was $3.56(\mathrm{SD}=0.83)$. This variable was significantly correlated the number of activities completed $(\mathrm{r}=0.31, \mathrm{p}=0.001)$. Parents in general expressed positive attitudes toward the program, and a clear majority (83.5\%) of parents agreed or strongly agreed that all parents should do at least one activity. Parents were asked if they felt more involved in their child's education as a result of the program. A mean score of 3.41 $(\mathrm{SD}=1.13)$ was obtained for this item with $58.8 \%$ of the parents agreeing or strongly agreeing.

The mean score for the variable Parent Problems was $2.24(\mathrm{SD}=0.68)$. The low mean indicates that parents tended to disagree that the items were problems they encountered. The evaluation of potential problems revealed that only a minority of parents agreed or strongly agreed that time, money, or materials were problems. A minority of parents agreed or strongly agreed that the instructions were too confusing, that they did not know enough science to work effectively on the activities, or that the activities were too difficult. The biggest problem with activities, from the parents' perspectives, was confusing instructions. On the Parent Questionnaire, $27.4 \%$ of the parents agreed or strongly agreed that the instructions in the activities were confusing. The problem dimension was significantly negatively correlated with the number of activities completed $(r=-0.44, p<0.001)$.

There were three items on the Parent Questionnaire that were planned as indicators of parents' comfort levels with being involved in science. The Cronbach's alpha reliability of this variable, Parent Comfort with Science, was 0.74. The mean score on this variable was $4.06(\mathrm{SD}=0.67)$. There was a significant correlation between Parent Comfort with Science and the number of activities completed $(r=0.43, p<0.001)$. 
Open Ended Responses

Another indicator of parents' thoughts about the program comes from a small questionnaire contained at the end of activity four. An open-response item asked the adult what could be done to make the activities better. The largest category of responses (12) was adults who expressed the idea that the program was okay as it was. The next largest category were adults (six) who felt more information could be given about the purpose of the activities, either how they fit into the curriculum or why they were important for life. Four adults expressed the problem with gathering materials for activities. There are direct references to the difficulty of obtaining rocks and soil during the week of this assignment, apparently because of the cold weather and snowstorms. Four adults commented on the difficulty of the activities. Of these four adults, one thought the instructions were confusing, two thought the activities were too difficult, and one thought the activities could be more challenging.

\section{Survey of Student Perspectives}

A five-point, Likert-item questionnaire administered to students (96\% were returned). Eight items on the Parent Questionnaire correspond to eight items on the Student Questionnaire. For example, students in the program were asked if they thought the activities had helped them learn science. The mean answer to this item was $3.51(\mathrm{SD}=0.97)$ with $61.9 \%$ of the students agreeing or strongly agreeing. When parents were asked if their children learned a lot from the activities a mean score of $3.61(\mathrm{SD}=0.89)$ was obtained with $64.3 \%$ agreeing or strongly agreeing.

Although these items were not distinct factors on either the parent or student questionnaire, the Cronbach's alpha reliability for these items was 0.92 and 0.86 for the Parent Questionnaire and the Student Questionnaire, respectively. These two sets of items on the questionnaires were significantly correlated with each other $(\mathrm{r}=0.44, \mathrm{p}<0.001)$. The mean score for the parents was $3.50(\mathrm{SD}=0.83)$ and for the students it was $3.16(\mathrm{SD}=0.82)$. Student attitudes were positive, but not as positive as their parents; the differences were statistically significant $(\mathrm{t}=3.50, \mathrm{df}=83, \mathrm{p}=.001)$.

In a factor analysis of the Student Questionnaire, three factors were found. The names and items of these factors are: (a) Student Benefits, (b) Student Views of Program and Parents, and (c) Time/Homework. The Cronbach alpha reliabilities and mean scores on these three sections are (a) 0.91 and $3.30(\mathrm{SD}=0.97)$, (b) 0.77 and $2.81(\mathrm{SD}=1.02)$, and (c) 0.66 and 3.30 $(\mathrm{SD}=1.17)$, respectively

In the items for the variable Student Benefits of the program, $45.5 \%$ of the students agreed or strongly agreed that they enjoyed the activities and $61.9 \%$ of the students agreed or strongly agreed that the activities helped them learn science. A majority of students indicated that the program should continue. Of the items in the variable Student Benefits of the program, the item with the most student disagreement was "I like science more because of the program." Approximately $45 \%$ of the students disagreed or strongly disagreed with this statement. The variable Student Benefits was significantly correlated with: Total Number of Activities 
Completed $(\mathrm{r}=0.38, \mathrm{p}<0.001)$, Parent Benefits $(\mathrm{r}=0.46, \mathrm{p}<0.001)$, Parent Problems $(\mathrm{r}=-0.51$, $\mathrm{p}<0.001)$, and Parent Comfort with Science $(\mathrm{r}=0.34, \mathrm{p}=0.001)$.

The second variable of the Student Questionnaire was Student Views of the Program and Parent. Only $21.6 \%$ of the students agreed or strongly agreed that the program helped them know their parent better, with a majority of students disagreeing or strongly disagreeing. A low percentage of agreement was also reported for the item "My parents are more involved in my education as a result of the program;" only $28.9 \%$ of the students agreed or strongly agreed with this statement. Many students (37.1\%) were undecided if their parents had learned a lot from doing the activities. Students were asked if they would rather have worked on by themselves or with a parent. Almost three-quarters of the students (72.3\%) indicated they would rather work with a parent than by themselves.

The third variable from the Student Questionnaire, Time/Homework, contained two items. For item one, "The activities required too much time," $48.4 \%$ of the students disagreed or strongly disagreed with this statement and $17.5 \%$ of the students were undecided. A majority of the students agreed or strongly agreed with the second item, "I would rather do program activity homework than regular homework."

Girls had higher scores than boys on each of the three variables on the Student Questionnaire. The means (and standard deviations) for the variable Student Benefits were 3.18 ( $\mathrm{SD}=1.08$ ) for boys and $3.38(\mathrm{SD}=0.88)$ for girls. For the variable Student Views of Program and Parents the mean for boys was $2.79(\mathrm{SD}=1.04)$ and the mean for girls was $2.84(\mathrm{SD}=1.01)$. The means for the variable Time /Homework were $3.27(\mathrm{SD}=1.26)$ for boys and $3.32(\mathrm{SD}=1.11)$ for girls. The mean number of activities completed was $6.79(\mathrm{SD}=3.04)$ for girls and 6.71 $(\mathrm{SD}=3.14)$ for boys. From an ANOVA, none of these differences was statistically significant.

\section{Parent and Student Interview Results}

Parents and students were classified into high, medium, and low participation categories based on the number of activities completed. For each teacher, separate parent and student interviews were conducted with participants from each category. Interviews with the participants revealed benefits and problems with the program. In the seven parent interviews, a few parents reported discoveries about their children.

It was kind of fun to actually see her in action. Like I said, you know I just get her report cards and see that, yeah, she is doing really well, and all "A's" and once in a while a "B." It was kind of fun seeing her in action. (Low Participation, Teacher 1, Mother)

This is Mom talking - but I always thought she was pretty smart, but I think she is even smarter than I thought. She is very good at coming up with the conclusions. She seems to have a real handle on it and she likes science more than I knew she did. She really does. (High Participation, Teacher 2, Mother)

A couple of parents indicated a change in their homework helping behavior. 
You know, it was fun. It was fun to do it together, but ugh, as I indicated on the questionnaire, I don't help her with any homework. So that was kind of a new experience for me. (Low Participation, Teacher 1, Mother)

I don't spend enough time with schoolwork. My wife does most of it. I help with the science homework. SPLASH [the name of the program] is a neat way to get involved. (High Participation, Teacher 2, Father)

A high-participation student described his observation of a change in his parents' behavior; "Before they used to tell me to do my homework and then after SPLASH, my Mom or my Dad would sit down and help me."

In comparing high participation parents with low participation parents, there seemed to be a difference in their perceived roles as parents in regards to schools. High participating parents expressed the importance of parental involvement. A high participating father indicated his involvement with his son's homework in the following passage:

[The father would say] "What's your homework log got written down?" [His son would say] "I've got this, this and this." So I say, "Well let's get to it." And then you have to sit there and push him because of what ever the days events were to get him to get the homework done or you have to say “Tom you've got math, you've got science, you've got some reading to do, what do you want me to help you with, if anything?" And he'll come up with, let's go over science. Or let's go over the math, or something he wants a little bit of help or a little bit of back-up to say what's right or what's wrong before he puts the answer down. (HP.T1.Father)

Low participating parents said statements that seemed to reflect their conscious or unconscious thoughts that schoolwork was something that should be between child and school, a factor that Sealey (1989) calls the "delegation model."

Mother: I guess, you know bottom line, what is your purpose of doing it outside of school instead of having them do it in school?

Interviewer: Is it fair to say that you basically feel they could do it at school and not at home?

Mother: Right. I'm just wondering what the purpose was to have the child to do it separately as homework. The main reason for it. (LP.T1.Mother)

What the children do at school is why I pay tax dollars. If I am going to be the teacher let them stay home. I will teach them all day. But you know you keep sending-your class might send one thing then another class sends something, before you know it I'm back in school. I graduated; I'm a mother now. I have other children to take care of and help with homework, so these time consuming projects just don't work for me. (LP.T2.Mother)

For one family, the delegation view of the mother coupled with the child's lack of enthusiasm for this type of homework created a situation where only one activity was done.

I asked him if he liked them and he said no. If he said he doesn't want to do them then why should I bother? Fine. Send it back and get the homework. (LP.T2.Mother) 
Procrastination appeared to be another problem. Students were give about one week of time to complete the activities and this time included the weekend. But often the parents wouldn't see them until there was little time left.

The biggest problem was Vance would pull the assignment out of his book bag after dinner and say, "Here, I have to have this done and turned in tomorrow." And then try and scramble and find whatever we needed to get it done that night, considering everything else he had to get done that night." (MP.T2.Mother)

But sometimes this would get put off until the night before it was due. And that has to do with my children not communicating or something, but that's not being able to organize our time. (HP.T2.Mother)

One parent indicated that the procrastination caused arguments.

You know it's hard to remember if you have a good morning and the afternoon is really bad, all you remember about is the really bad afternoon you had. So that's kind of the way I am remembering it. I know we had fun doing the whirly thing. Running up and down the stairs after it. That was pretty fun. At first I was real excited by it because we were doing it together and everything. But then it got, it was like a real switch, we were waiting for the last possible second and then having an argument over getting it done. (MP.T1.Mother)

\section{Discussion and Implications}

This study provides evidence that it is possible to implement an inquiry hands-on science, at-home, parental involvement program where the manipulatives are not sent home. Participation rates were encouraging but care must be used in making materials easier to obtain, instructions less confusing, and using activities focused on the school curriculum. Students were exposed to more hands-on science experiences and received the benefit of one-on-one adult mentoring. As we approach the parent-child-school interactions of the mesosphere, there were positive aspects reported by both the parent and child on this type of school work. Parents generally had positive views of the program. While student attitudes were not as positive as their parents, a majority of students preferred this type of homework to traditional homework. As with the study by Gennaro and Lawrenz (1992), female students had more positive attitudes than male students.

The completion data suggest that this type of homework can be completed at the same level as traditional homework. Because parents write comments and sign the sheets, however, there is much more assurance that when a student submits this work that it was actually done by the student and not copied from another student. Declines in participation were evident when materials were difficult to collect. The last two activities also showed declines. In these activities there was a greater focus on inquiry and the topics were not aligned with what was being learned in the classroom. The declining participation rates towards the end of the program could have also been caused by fatigue for doing the program. There was a significant positive correlation with number of activities completed and the Parent Comfort variable, and a significant negative correlation with number of activities completed and the variable Parent Problems. As might be expected, science comfort led to doing more activities, 
and encountering or perceiving problems such as materials or unclear directions resulted in lower levels of completion.

While parents were not expected to have the expertise of science teachers, there appeared to be a range of abilities and desires to assist in learning. Future studies could explore what is happening in the Zone of Proximal Development as parents and children work together. Most parents indicated they thought their children profited from their involvement. But some parents may need more assistance about involvement in general and more specifically their role in at-home hands-on inquiry activities.

Perhaps the richest information came from interviewing participants in the program. The program seemed to offer the most for students whose parents were disconnected from their school education. However, lack of participation by some families may have reduced the impact of the program. Low participation parents held, what Seeley (1989) calls a delegatory view of their role in education. This view came out strongly in the interviews with low participation parents. Low participation students were found to be disinterested in the program. Were they disinterested because of their lack of participation, or was their disinterest a factor in not getting the parents more involved? If the latter is true, methods to motivate the students to want to participate need to be explored. Their enthusiasm may help some parents overcome their reluctance to participate.

The interview results suggested that participating parents generally enjoyed the activities. Data from several studies (e.g. Manis, Thomas, Sloat, \& Davis; 1989; Rayman \& Brett, 1995; Olszewski \& Yasumoto, 1995) suggest parent attitudes toward math and science are important in influencing students pursuing study and careers in these areas. Perhaps enjoyable experiences in science will help parents develop better attitudes towards its study. Observations of parents such as, "I think she is even smarter than I thought. She is very good at coming up with the conclusions. She seems to have a real handle on it and she likes science more than I knew she did" reveal that parents learned more about their children's interests and abilities in science. This may help parents encourage children who have abilities or interest in science inquiry to pursue other science learning experiences.

\section{Summary}

This study explored benefits and problems of having sixth-grade students and parents engage in science activities at home. The data indicates that the level of completion of activities was as high as for normal homework assignments. The majority of parents and students had positive feelings toward aspects of the program, thought the program should continue, and thought the students had learned from it. A majority of students preferred these activities to regular homework and would rather work with parents than work alone. The biggest problem for parents was the clarity of the activity directions. A majority of parents also agreed that they had helped their children by working on the activities with them. The program helped parents to be involved and most parents indicated they helped their child learn science. 


\section{References}

Arnold, L. B., \& Birne, A. M. (1995). Parent University: A new program in Union City, New Jersey, ensures the success of students by educating their parents. Science Teacher, 62(8), 29-31.

Ash, D. (2003). Dialogic inquiry in life science conversations of family groups in museums. Journal of Research in Science Teaching, 40, 138-162. http://dx.doi.org/10.1002/tea.10069

Berla, N. (1991). Parent involvement at the middle school level. The ERIC Review, 1(3), $16-17,20$.

Bobbitt, N., \& Paolucci, B. (1975). Home as a Learning Center. Final Report. East Lansing: Michigan State University. Retrieved from ERIC Database (ED120033)

Bronfenbrenner, U. (1979). The ecology of human development. Cambridge, MA: Harvard University Press. http://dx.doi.org/10.1037/0012-1649.22.6.723

Bronfenbrenner, U. (1986). Ecology of the family as a context for human development: Research perspectives. Developmental Psychology, 22, 723-742.

Callanan, M.A., \& Jipson, J. L. (2001). Explanatory conversations and young children's developing scientific literacy. In K. Crowley, C. D. Schunn, \& T. Okada (Eds.), Designing for science: Implications from everyday, classroom, and professional settings (pp. 21-49). Mahwah, NJ: Erlbaum. http://dx.doi.org/10.1016/0885-2014(92)90012-G

Callanan, M. A., \& Oakes, L. A. (1992). Preschoolers' questions and parents' explanations: Causal thinking in everyday activity. Cognitive Development, 7, 213-233.

Caplan, N., Choy, M. H., \& Whitmore, J. K. (1992). Indochinese refugee families and academic achievement. Scientific American, 288(2), 36-42. http://dx.doi.org/10.1038/scientificamerican0292-36

Carnegie Council on Adolescent Development. (1989). Turning points: Preparing American youth for the 21st century. New York: Carnegie Corporation.

Crowley, K., \& Galco, J (2001). Everyday activity and the development of scientific thinking. In K. Crowley, C. D. Schunn, \& T. Okada (Eds.), Designing for science: Implications from everyday, classroom, and professional settings (pp. 393-413). Mahwah, NJ: Erlbaum.

David, M.E. (1993). Parents, Gender and Education Reform. Cambridge, MA: Polity Press:

Department for Education and Employment. (1998). Home-School Agreements: guidance for schools. London: Department for Education and Employment.

Desforges, C., \& Abouchaar, A. (2003). The impact of parental involvement, parental support and family education on pupil achievement and adjustment: A literature review. Department for Education and Skills. London: Queen's Printer.

Dodd, A. W., \& Konzal, J. L. (2000a). Parents and educators as real partners. Education Digest, $6,18-22$. 
Dodd, A. W., \& Konzal, J. L. (2000b). Making our High Schools Better: How Parents and Teachers Can Work Together. New York: St. Martin's Press

Downey, D. B. (2002). Parental and family involvement in education. In A. Molnar (Ed.), School reform proposals: The research evidence. Tempe, AZ: Education Policy Unit, College of Education. Arizona State University. Retrieved from: http://www.asu.edu/educ/epsl/EPRU/documents/EPRU\%202002-101/ Chapter\%2006-Downey-Final.pdf

Eccles, J. S., \& Harold, R. D. (1993). Parent-School involvement during the early adolescent years. Teachers College Record, 94(3), 568-587.

Epstein, J. L. (1992). School and family partnerships. In M. Aikin (Ed.,), Encyclopedia of educational research (pp. 1139-1151). New York: MacMillan

Epstein, J. L., \& Conners, L. J. (1992). School and family partnership in middle Grades and high schools. Practitioner, 18(4). (ERIC Document Reproduction Services No. ED347638)

Epstein, J. L., \& Sanders, M. G. (2000). Connecting home, school, and community: New directions for social research. In M. T. Hallinan (Ed.), Handbook of the sociology of education (pp. 285-306). New York: Kluwer Academic/ Plenum Publishers.

Farenga, S. J. \& Joyce, B. A. (1998). Science-related attitudes and science course selection: A study of high-ability boys and girls. Roeper Review, 20(4), 247- 51. http://dx.doi.org/10.1080/02783199809553901

Farenga, S. J., \& Joyce, B. A. (1999). Intentions of young students to enroll in science courses in the future: An examination of gender differences. Science Education, 83(1), 55-75. http://dx.doi.org/10.1002/(SICI)1098-237X(199901)83:1<55::AID-SCE3>3.0.CO;2-O

Fleer, M. \& Rillero, P. (1999). Family involvement in science education: What are the outcomes for parents and students? Studies in Science Education, 34, 93-114. http://dx.doi.org/10.1080/03057269908560150

Geake, J. G. (1993). Parents as a resource for science and technology education. The Australian Science Teachers Journal, 39(2), 52-54.

Gennaro, E. D., Hereid, N., \& Ostlund, K. (1986). A study of the latent effects of family learning courses in science. Journal of Research in Science Teaching, 23(9), 771-81. http://dx.doi.org/10.1002/tea.3660230903

Gennaro, E. D., \& Larenz, F. (1992). The effectiveness of take-home science kits at the elementary level. Journal of Research in Science Teaching, 29(9), 985-94. http://dx.doi.org/10.1002/tea.366029090

George, R. \& Kaplan, D. (1998). A structural model of parent and teacher influences on science attitudes of eight graders; evidence from NELS. Science Education, 82(1), 93-111. http://dx.doi.org/10.1002/(SICI)1098-237X(199801)82:1<93::AID-SCE5>3.0.CO;2-W

Graika, T. (1981). Parents: Partners in science. Science and Children, 19(1), 13-15. 


\section{Macrothink}

Journal of Studies in Education

ISSN 2162-6952

2016, Vol. 6, No. 1

Hashmi, A., \& Akhter, M. (2013). Assessing the parental involvement in schooling of children in public/private schools, and its impact on their achievement at elementary level. Journal of Educational Research, 16(1), 27-38.

Hooker, K. L. (2014). Science homework with video directions for parents: The impact on parental involvement and academic achievement. ProQuest Dissertations \& Theses Global: Social Sciences. Retrieved from ProQuest Database.

Katz, L. G. (1984). Contemporary perspectives on the roles of mothers and teachers. In More talks with teachers (pp. 1-26). Champaign, IL: ERIC Clearinghouse on Elementary and Early Childhood Education. Retrieved from ERIC Database (ED250099).

Kohl, G. O., Lengua, L. J., \& McMahon, R. J. (2000). Parent involvement in school conceptualizing multiple dimensions and their relations with family and demographic risk factors. Journal of School Psychology, $38, \quad 501 \quad$ - 523. http://dx.doi.org/10.1016/S0022-4405(00)00050-9

Manis, J. D., Thomas, N. G., Sloat, B. F., \& Davis, C. S. (1989). An analysis of factors affecting choice of majors in science, mathematics and engineering at the University of Michigan. Research report \#23 (pp. 61). Ann Arbor: University of Michigan. Retrieved from ERIC Database (ED356954).

McNeal, R. B. (2014). Parent Involvement, academic achievement and the role of student attitudes and behaviors as mediators. Universal Journal of Educational Research, 2(8), 564-576.

Meichtry, Y. J. (1992). Using laboratory experiences to develop the scientific literacy of middle school students. School Science and Mathematics, 92(8), 437-441. http://dx.doi.org/10.1111/j.1949-8594.1992.tb15625.x

Misiti, F. L. Jr., Shrigley, R. L., \& Hanson, L. (1991). Science attitude scale for middle school students. Science Education, 75(5), 525-40. http://dx.doi.org/10.1002/sce.3730750504

Nye, C., Turner, H., \& Schwartz, J. (2006). Approaches to parent involvement for improving the academic performance of elementary school age children. London: The Campbell Collaboration. http://dx.doi.org/10.4073/csr.2006.4

Olszewski, K. P., \& Yasumoto, J. (1995). Factors affecting the academic choices of academically talented middle school students. Journal for the Education of the Gifted, 18(30), 298-318. http://dx.doi.org/10.1177/016235329501800306

Osborne, J.F., \& Collins, S. (2000). Pupils' and parents' views of the school science curriculum. London: King's College.

Patton, M. Q. (1990). Qualitative evaluation and research methods. Newbury Park: Sage Publications. 
Rayman, P., \& Brett, B. (1995). Women science majors: What makes a difference in persistence after graduation? Journal of Higher Education, 66(4), 388-414. http://dx.doi.org/10.2307/2943794

Reynolds, A. J. (1991). The middle school process: Influences on science and mathematics achievement from the longitudinal study of American youth. Adolescence, 26(101), 132-58.

Ritblatt, S. N., Beatty, J. R., Cronan, T. A., \& Ochoa, A.M. (2002). Relationships among perceptions of parent involvement, time allocation, and demographic characteristics: Implication for policy formation. Journal of Community Psychology, 30, 519-549. http://dx.doi.org/10.1002/jcop.10018

Seeley, D. S. (1989). A new paradigm for parent involvement. Educational Leadership, 47(2), 46-48.

Sheldon, S. B., \& Epstein, J. L. (2005). Involvement counts: Family and community partnerships and mathematics achievement. Journal of Educational Research, 98, 196-206. http://dx.doi.org/10.3200/JOER.98.4.196-207

Siegel, D. R., Esterly, J., Callanan, M. A., Wright, R., \& Navarro, R. (2007). Conversations about science across activities in Mexican-descent families. International Journal of Science Education, 29(12), 1447-1466. http://dx.doi.org/10.1080/09500690701494100

Simpkins, S. D., Davis-Kean, P. E., \& Eccles, J. S. (2006). Math and science motivation: A longitudinal examination of the links between choices and beliefs. Developmental Psychology, 42(1), 70-83. http://dx.doi.org/10.1037/0012-1649.42.1.70

Tudge, J. (1991). Feedback as a "Zone of Proximal Development." Paper presented at the biennial meetings of The Society for Research in Child Development, April 1991, Seattle. Retrieved from ERIC Database (ED349159).

US Department of Education. (2004). Parent Involvement: Title 1. Washington, DC: US Department of Education. Retrieved from http://www.ed.gov/programs/titleiparta/parentinvguid.pdf

Verma, S. (1994). Science a family affair. Education Canada, 34(4), 35-37.

Veronneau, M. (2010). Predicting change in early adolescent problem behavior in the middle school years: A mesosystemic perspective on parenting and peer experiences. Journal of Abnormal Child Psychology, 38(8), 1125-1137. http://dx.doi.org/10.1007/s10802-010-9431-0

Vygotsky, L. S. (1979). Mind in society: The Development of higher psychological processes. Cambridge, MA: Harvard University Press.

Wertsch, J. V. (1985). Vygotsky and the social formation of mind. Cambridge, MA: Harvard University Press.

Williams-Norton, M., Residorf, M., \& Specs, S. (1990). Home is where the science is. Science and Children, 27(6), 12-15. 
Wimberly, G. L., \& Noeth, R. J. (2004). Schools involving parents in early postsecondary planning. Iowa City, IA: ACT.

Zellman, G. L., \& Waterman, J. M. (1998). Understanding the impact of parent school involvement on children's educational outcomes. The Journal of Educational Research, 91, 370-380. http://dx.doi.org/10.1080/00220679809597566 